\title{
Analisis Peningkatan Produksi Pada Sumur Minyak Dengan Metode Partial Water Shut Off Dalam Meningkatkan Rasio Keberhasilan Partial Water Shut Off Pada Lapangan Hawa
}

\author{
Fitrianti $^{1}$, Novrianti $^{1}$ \\ ${ }^{1}$ Program Studi Teknik Perminyakan Universitas Islam Riau
}

\begin{abstract}
From year to year the number of oil production will be reduced and the amount of water production will grow, so will cause problems in managing the water. Some of the problems that arise are limitations in the surface water treatment systems, the availability of water treatment chemicals, and declining well productivity. Doing some work over to lower the value of water production and increase the value of oil production, one of which is the partial water shut off. On the hawa field, some job well done partial water shut off. The results of such work nothing works and nothing failed. Analysis performed on the job partial water shut off with the observation of the historycompletion and the processing of data and calculation of the value of production history OOIP to get the value of remaining reserves. After analysis, it was found some causes of work partial water shut off the well would be successful if it fulfills several criteria such as: the value of remaining reserves are still large enough, she had never done work partial water shut off in the layer and selecting the type of isolation right tool. While the cause of such failures is that the well had done work partial water shut off the same perforation interval. The criteria are very important and necessary in deciding the work partial water shut off the a better well done or not.
\end{abstract}

Keywords: Partial water shut off, Work over, Water cut

Corresponding Author e-mail address: fitrianti@eng.uir.ac.id

\section{PENDAHULUAN}

Pada tahap awal produksi minyak, oil companies akan berusaha untuk memproduksikan minyak sebesar - besarnya dengan mengabaikan produksi air yang saat itu masih cukup kecil untuk ditangani di permukaan meskipun sumur produksi tersebut akan mengalami water coning. Tidak dipungkiri lagi bahwa sumur dengan umur produksi yang sudah cukup tua, nilai water cut akan semakin meningkat setiap waktunya karena produksi di awal yang dilakukan secara besar - besaran. Permasalahan produksi air yang berlebih ini akan berdampak pada rate oil yang akan semakin mengecil dan fasilitas produksi permukaan yang terbatas serta biaya pengangkatan dan pemisahan antara minyak dengan air akan terasa menjadi lebih mahal.

Lapangan Hawa merupakan lapangan yang sudah cukup lama beroperasi yaitu sejak 1984. Hingga kini lapangan Hawa masih tetap memproduksi minyak dari formasi Bekasap dan Bangko dengan nilai water cut 96\% - 99\%. Lapangan Hawa memiliki 1 fasilitas produksi permukaan gathering station Zamrud Area, dimana lapangan ini harus berbagi dengan 9 lapangan yang lain dalam menyumbangkan fluida produksi pada gathering station tersebut. Asumsi produksi per-hari fluida pada satu sumur adalah 1000 BFPD dengan water cut $97 \%$ dan nilai produksi minyak adalah 30 BOPD.

Crude oil adalah salah satu fluida yang diharapkan dapat diproduksikan secara optimum ke permukaan. Pada awal tahap produksi, nilai oil cut akan sangat tinggi yang berarti produksi minyak 
sangat besar. Namun, seiring dengan berjalannya produksi, tekanan reservoir mengalami penurunan yang menyebabkanproduksi minyak berkurang, dan produksi air meningkat. Peningkatan produksi air disebabkan oleh pori batuan yang sebelumnya diisi oleh minyak (minyak diproduksikan) diisi oleh air yang berasal dari aquifer sehingga, air ini juga ikut terproduksikan. Kenaikan produksi air menjadi suatu permasalahan, karena terbatasnya fasilitas pengolahan air dan pertimbangan efisiensi produksi yang diinginkan untuk diproduksikan adalah minyak sebanyak - banyaknya dan produksi air seminimal mungkin.

Lapangan hawa memiliki produksi air yang tinggi dengan nilai produksi minyak yang rendah. 27 sumur pada lapangan tersebut pernah didapatkan nilai water cut-nya mencapai 99\%, dan oil cut-nya hanya $1 \%$. Namun, sumur tersebut masih tetap diproduksikan karena masih bernilai ekonomis, dan belum mencapai titik economic limit.Mengingat begitu banyaknya masalah laju produksi pada suatu sumur minyakkarena air, maka perlu dianalisis penyebab - penyebab terjadinya penurunan laju produksi pada suatu sumur dan penanggulangannya. Program perawatan sumur dapat dilakukan dengan Kerja Ulang Sumur (workover). Seperti dengan mengubah sistem pengangkatan (artificial lift), merangsang formasi (stimulasi), melakukan kerja ulang pindah lapisan, menutup zona yang tidak lagi produktif, dan menutup zona air yaitu water shut off (WSO) dan partial water shut off (PWSO).

Dalam upaya menurunkan produksi air dan meningkatkan produksi minyak, beberapa sumur pada lapangan hawa di lakukan pekerjaan partial water shut off. Beberapa dari pekerjaan tersebut ada yang berhasil dan ada yang gagal. Analisis mengenai keberhasilan dan kegagalan dilakukan untuk mendapatkan kriteria - kriteria yang selanjutnya akan digunakan dalam meningkatkan rasio keberhasilan pekerjaan partial water shut off pada lapangan hawa. Tujuan penelitian ini untuk menentukan kandidat sumur untuk dilakukan analisis partial water shut off dan melakukan analisis terhadap sumur terpilih pada lapangan hawa dan menentukan kriteria - kriteria partial water shut off untuk meningkatkan rasio keberhasilan.

\section{METODE PENELITIAN}

Metode yang dilakukan pada penelitian ini dengan mengumpulkan data - data yang berhubungan dengan data reservoir, sejarah produksi, data swabbing job dan water cut. Setelah itu dilakukan analisis data yang membawa kepada kesimpulan yang merupakan tujuan dari penelitian. Merupakan indeks yang menunjukkan kemampuan formasi dalam memproduksikan fluida reservoir.

\section{HASIL DAN PEMBAHASAN}

Keberhasilan pekerjaan partial water shut offmemiliki beberapa faktor penentu yaitu:

1. Nilai indeks produktifitas sumur menurun setelah partial water shut off

2. Nilai water cut turunpartial water shut off

3. Nilai total fluida secara menyeluruh turunpartial water shut off

4. Nilai rate minyak naikpartial water shut off

Jika semua syarat tersebut terpenuhi maka dapat dikatakan pekerjaan partial water shut off yang telah dilakukan berhasil. Namun, apabila salah satu syarat tidak terpenuhi maka pekerjaan partial water shut off dikatakan gagal. 
Partial water shut off perlu dilakukan pada sumur dengan performa tinggi namun produksi airnya sudah mencapai angka mengkhawatirkan, karena terbatasnya sistem operasi permukaan untuk menampung banyaknya produksi air. Jika dari 1 sumur saja mencapai 3000 BWPD, maka lapangan yang terdiri dari beberapa sumur dengan produksi air yang tinggi juga akan menyebabkan bertambahnya biaya pemurnian air yang ikut terproduksi bersama minyak karena untuk memisahkan emulsi minyak dan air diperlukan beberapa bahan kimia seperti demulsifier dan reversedemulsifier.

Lapangan hawa memiliki 4 lapisan formasi yang produktif yaitu Bekasap I, Bekasap II, Bangko I, dan Bangko II. Dari 4 lapisan inilah diproduksikan hidrokarbon/minyak bumi. Lapangan hawa memiliki 25 sumur produksi. Sumur - sumur yang akan dianalisis harus menggunakan metode partial water shut off kemudian memiliki nilai water cut yang cukup tinggi yaitu sekitar 97\% - 99\%. Ada beberapa sumur yang nilai water cut-nya tidak mencapai angka 90\%, namun dilakukan partial water shut off. Penyebabnya adalah pada saat itu air sangat tidak diperlukan dalam hal pressure maintenance (water flood) serta sangat terbatasnya sistem pengolahan permukaan sehingga kenaikan nilai water cut $1 \%$ saja bisa menjadi masalah. Seleksi sumur yang dianalisis dilakukan dengan pengamatan terhadap sejarah komplesi sumur yang dilakukan pekerjaan/workoverpartial water shut off. Beberapa workover selain partial water shut off yang dilakukan pada lapangan tersebut diantaranya adalah water shut off, reverse flow, acid stimulation, dan fracturing. Setelah dilakukan seleksi, terpilih beberapa sumur untuk dilakukan analisis.

Analisis peningkatan produksi sumur minyak ini dilakukan pada 4 sumur yang sistem produksinya melakukanpekerjaanpartial water shut off pada lapangan hawa yaitu sumur HW\#03, HW\#20, HW\#25, dan HW\#28. Beberapa sumur yang dianalisis memiliki umur yang cukup tua. SumurHW\#20 mulai diproduksikan pada 1986 hingga 2015. HW\#03 mulai diproduksikan pada tahun 1993, HW\#25 diproduksikan mulai dari 1988, dan HW\#28 mulai diproduksikan pada tahun 1990. Dari kelima sumur tersebut, hanya sumur HW\#20 yang sudah tidak diproduksikan pada tahun 2016 karena water cut yang sudah mencapai $100 \%$.

\section{Sumur HW\#03}

Sumur ini telah berproduksi hingga 23 tahun dengan nilai kumulatif produksi adalah 562,700 barrel. HW\#03 memiliki reserve sebesar 636,859 barrel.HW\#03 memproduksi fluida dari lapisan reservoir Bekasap I $1440 \mathrm{ft}$ dengan interval perforasi awalnya 1581' - 1594' kemudian dilakukan penambahan zona perforasi $5 \mathrm{ft}$ diatas perforasi awal menjadi 1576'. Hingga saat ini hanya tersisa 74,159 bbl oil yang belum diproduksikan ke permukaan. HW\#03 telah dilakukan beberapa kali workover dan well service seperti recondition pump, size up pump, dan partialwater shut off. Untuk pekerjaan partialwater shut off, dilakukan sebanyak 5 kali terhadap sumur ini dengan harapan dapat meningkatkan nilai Np. Dari beberapa kali partialwater shut off, diantaranya ada dua kali berhasil dan 3 kali gagal.

\section{Sumur HW\#20}

Sumur ini diproduksikan mulai dari tahun 1986.Sumur HW\#20 diproduksikan dari 3 layer, yaitu 1400 $\mathrm{ft}, 1460 \mathrm{ft}$, dan $1570 \mathrm{ft}$. Pada initial completion, sumur hanya diproduksikan dari layer $1570 \mathrm{ft}$. Kemudian pada Januari 1990, layer $1570 \mathrm{ft}$ ditutup seluruhnya (water shut off) dan produksi berpindah ke layer $1400 \mathrm{ft}$ dan $1460 \mathrm{ft}$. Hingga saat ini, sumur HW\#20 memproduksikan sebanyak 2,768,296 
BBL minyak bumi. Pada sumur ini telah dilakukan beberapa pekerjaan work over dan well service. Sumur HW\#20 juga dilakukan water shut off dengan metode squeeze off.

\section{Sumur HW\#25}

Sumur ini mulai diproduksikan pada Juni 1988. Sumur ini diproduksikan dari layer $1440 \mathrm{ft}, 1460 \mathrm{ft}$, $1500 \mathrm{ft}$, dan $1570 \mathrm{ft}$. Hingga saat ini, sumur telah menyumbangkan minyak sebesar 1,780,393 BBL. Pada saat initial completion, sumur hanya memproduksikan minyak dari layer $1570 \mathrm{ft}$, dengan membuka 2 interval perforasi.

\section{Sumur HW\#28}

Sumur HW\#28 mulai diproduksikan pada Januari 1990 dengan memproduksikan fluida dari layer 1440 ft, $1460 \mathrm{ft}$, dan $1500 \mathrm{ft}$. Pada saat initial completion, sumur diproduksikan dari semua layer. Hingga saat ini, sumur ini telah menyumbangkan minyak sebesar 1,780,393 BBL. Pada sumur HW\#28 dilakukan dua kali pekerjaan partial water shut off ada layer $1500 \mathrm{ft}$ dan layer $1460 \mathrm{ft}$.

\section{KESIMPULAN}

1. Kandidat sumur terpilih untuk dilakukan analisis pekerjaan PWSO dengan melakukan pengamatan terhadap data komplesi lapangan Hawa adalah sumur HW\#03, HW\#20, HW\#25, dan HW\#28.

2. Analisis yang telah dilakukan terhadap sumur terpilih yaitu, pada sumur HW\#03 PWSO yang mengalami kesuksesan, nilai PI setelah dilakukan PWSO turun 0.07, nilai WC berkurang29\%, total fluida dari 654 BFPD menjadi 1089 BFPD dengan penambahan kapasitas pompa, rate oil meningkat sebesar 376 BOPD, kemudian untuk PWSO (2) nilai PI turun 1.6, WC turun 1\%, total fluida turun 1043 BFPD dan rate oil meningkat 2 BOPD. Sumur HW\#20 sebelum PWSO (1) nilai PI menurun 4.33, WC turun 16\%, total fluida turun 564 BFPD dan rate oil meningkat 1099 BOPD, kemudian untuk PWSO (2) nilai PI turun 2,8, WC turun 20\%, total fluida turun 1656 BFPD dan rate oil meningkat 164 BOPD. Sumur HW\#25 setelah dilakukan PWSO nilai PI menurun 3.4, WC menurun $7 \%$, total fluida turun 68 BFPD dan rate oil meningkat 127 BOPD. Sumur HW\#28 sebelum PWSO (1) nilai PI turun 0.12, WC turun 33\%, total fluida turun 88 BFPD dan rate oil meningkat 619 BOPD, kemudian untuk PWSO (2) nilai PI turun 2, WC turun 38\%, total fluida turun 591 BFPD dan rate oil meningkat 551 BOPD.

3. Kriteria seleksi dari pekerjaan PWSO untuk meningkatkan rasio keberhasilan pekerjaan PWSO di masa mendatang adalah PWSO sebaiknya dilakukan pada sumur yang tidak pernah dilakukan PWSO sebelumnya. PWSO sebaiknya dilakukan pada interval perforasi yang sebelumnya tidak pernah menerima perlakuan PWSO, bila interval tersebut pernah menerima perlakuan PWSO maka dilakukan lagi PWSO dengan menerapkan media isolasi selain packer yaitu chemical dansqueeze. PWSO dengan menggunakan metode mekanik sebaiknya memilih jenis packer double cup packer. PWSO dilakukan pada sumur yang berumur 2-6 tahun. Lakukan running RST (reservoir saturation tool) untuk mengetahui secara pasti batas dari WOC pada sumur yang akan dilakukan PWSO agar zona yang diisolasi tepat.

\section{DAFTAR PUSTAKA}

Chan, KS. 1995. Water Control Diagnostic Plot. SPE Annual Technical Conference \&Exhibition. USA.

Brown, Kemit. (1993). The Technology Of Artificial Lift Method. Oklahoma: The University Of Tulsa. 
Permana, D., et al. (2015). Extracting Lessons Learned of 35 Water Shut-off Jobs in Mature Field. SPE/IATMI Asia Pacific Oil \& Gas Conference and Exhibiton. Indonesia.

Permana, D., et al. (2013). Successful Water Shut off Treatment-Brown Field Success Story. SPE Asia Pacific Oil \& Gas Conference and Exhibiton. Indonesia.

Sumarna, D. (2011). Wellwork and Completion. Duri: CPI. 